\title{
Quality characteristics of ready-to-serve (RTS) thandai beverage during storage
}

\author{
Manpinder Kaur $^{1}$, Rekha Chawla ${ }^{1}$, Santosh K Mishra $^{2}$ and S Sivakumar ${ }^{1}$
}

Received: 29 August 2019 / Accepted: 04 October 2019 / Published online: 31 December 2019

(c) Indian Dairy Association (India) 2019

\begin{abstract}
The present study was conducted to evaluate the shelf life of traditional Indian composite milk beverage; thandai in ready to serve (RTS) form at refrigeration temperature. Pasteurized thandai drink was prepared using variety of nuts added in appropriate amount using standard methodology. Product was packed in cleaned, sterilized glass bottles with plastic seal on to the top and stored at refrigerated $\left(4 \pm 1^{\circ} \mathrm{C}\right)$ temperature. The physico-chemical, microbiological, instrumental colour as well as sensory quality of the stored product was studied on daily basis, considering the short life span of pasteurized drink. Results indicated that the product became sensorily unacceptable after 10 days under refrigerated temperature wherein continuous decrease of sensory scores in thandai were observed and proximate parameters like tyrosine, TBA, and peroxide value increased during storage, indicating a life of 10 days. Thus, an acceptable quality thandai drink can be kept with its intact sensory profile for about 10 days.
\end{abstract}

Keywords: Nuts, Physico-chemical properties, Traditional drink, Storage study, Shelf life

\footnotetext{
${ }^{1}$ Department of Dairy Technology

${ }^{2}$ Department of Dairy Microbiology

Guru Angad Dev Veterinary and Animal Sciences University (GADVASU), Ludhiana,141004, Punjab, India

Rekha Chawla ( $\square$ )

Assistant professor, Department of Dairy Technology,

College of Dairy Science and Technology, GADVASU, Ludhiana, India 141004

Phone: +91-7020383177 Fax: 0161-2553313

Email: mails4rekha@gmail.com
}

\section{Introduction}

Thandai, a well-known regional specific traditional milk-based and nuts infused beverage, is popular in Rajasthan and certain other Northern states of India. The drink is served in summer and relished as a delicacy during festive season in India. It is prepared with a mixture of almonds, fennel seeds (obtained from Foeniculum vulgare), khuskhus (white poppy seeds obtained from Papaver somniferum), pepper, cardamom, saffron, milk and sugar and is served chilled, with some other optional ingredients. Thandai is easily digestible, highly refreshing, thirst quenching, tempting and nutritionally far superior to many synthetic and aerated drinks.

To prepare thandai, firstly well grinded and peeled almonds along with cardamom and various seeds were mixed together to prepare a smooth and fine paste. This mixture was then further incorporated with other ingredients followed by the straining. The beverage is served chilled for its exotic taste and flavour. Thus, Thandai proves itself to be a nutrient crammed pabulum that invigorates body with its salubrious persona, upshot of alimental macro and micro nutrients both from nuts and milk.

Since there are only few milk-based variants with wholesome amount of nuts present are available and amongst these, to find a drink with the goodness of nuts along with peculiar seeds is once in blue moon situation. The seeds used in thandai are idiosyncratic seeds of watermelon, muskmelon, pumpkin and cucumber. Each kind has its own characteristics and benefits. Cucurbit kernels are quite rich in calcium, iron and phosphorus (Madaan and Lal, 1984). Additionally, many proteins from cucurbit seed reported pharmacological activities, including anti-diabetic, anti-fungal, antibacterial, anti-inflammatory and antioxidant activity (Wani et al.., 2010). EI-Adaway and Taha (2001) reported higher fibre content in watermelon and pumpkin seed kernels with considerable amounts of $\mathrm{P}, \mathrm{K}, \mathrm{Mg}, \mathrm{Mn}$, and $\mathrm{Ca}$. Thus, the ingredients used in preparation of the beverage have been medicinally proven.

Thandai being a traditional Indian drink, lacks International and national level research work and therefore the literature pertaining to the same is not available. Also, as on now, as per the available 
literature none of the study has been undertaken to prepare and evaluate the performance of this beverage at scientific level. However various other flavoured dairy drinks have been prepared at various research institutes like rabadi, lassi with enhanced health benefits etc. Also, there are a fewer brands of thandai available in the market which are either syrup based or in powder form and the formulations of these available brands varies a lot. Thus, in the absence of technical know-how, the large-scale production of this region-specific milk beverage in organized sector in ready-to-drink (RTD) form is a challenging task, which requires scientific investigations in terms of its characterization, standardization of technological parameters, strategic interventions for ensuring the safety and enhancing the shelflife. Therefore, as an initiative, characterization of the thandai on descriptive scale has been done (Chawla et al. 2018). To assess storage life of the drink, a pasteurized version of ready-to-serve drink was done. Though to enhance life span, sterilization treatment was also tried but due to high amount of nuts infused drink, gelation occurred with many of the trials undertaken along with different stabilizers with their respective different concentrations. Thus, the paper reveals the storage stability of the prepared drink at refrigerated storage.

\section{Materials and Methods}

The samples of thandai for storage study were prepared and analysed for physico-chemical, textural and microbiological characteristics in the Dairy Technology Laboratory, College of Dairy Science and Technology, Guru Angad Dev Veterinary and Animal Sciences University, Ludhiana, using analytical grade chemicals and the requisite chemicals were prepared with glass distilled water.

\section{Raw materials}

\section{Milk}

Premium quality milk was received for the preparation of readyto-serve thandai drink, from Experimental Dairy Plant, College of Dairy Science and Technology, Guru Angad Dev Veterinary and Animal Sciences University, Ludhiana, in a clean utensil. Other basic ingredients like refined sugar, food grade apple green colour were procured from the local market whereas flavours of cardamom and thandai flavour, were procured under brand name 'Peacock' from Gogia chemicals, Greater Noida (U.P.), India.

\section{Preparation of Nuts}

\section{Storage of Raw Nuts}

The nuts (like seeds of cucumber, papaya, muskmelon, watermelon and additionally cashews) procured from market were properly sorted and sifted to carefully examine the quality and to remove any unwanted particles, if present. Further, these nuts were separately packed into plastic containers to safeguard the consistency and uniformity throughout the study for mix preparation.

\section{Calculations for nuts mixture}

Calculation plays a major role in mixture preparation to ensure equal quantities of all five nuts in the formulation. To prepare drink with $8 \%$ of total nuts, approximately 1.6 grams of each type of nutswere added using an accurately calibrated digital weighing balance.

\section{Preliminary preparation of nuts}

Accurately weighed almonds were soaked overnight and peeled off in the morning. Other four types of seeds were accurately measured and mixed together in a container and heated in microwave for one minute so as to remove extra moisture and to give a thermal treatment for the inherent micro-flora, thus preparing the nuts ready to grind. Further, all these seeds along with peeled off almonds were ground in a food processor until fine powder was prepared. The powder was taken in a thick base karahi and roasted till it turned light brown in colour and released a particular nutty aroma. This treatment prevents enzymatic browning of nuts and generates various aroma compounds. The total time of roasting consisted of 7-9 minutes, which has been reported as optimum for oxidative stability and preservation of tocopherols and polyunsaturated fatty acids (Yoshida et al. 2006). The prepared mix was utilized the same day to maintain freshness as well as to avoid flavour and colour defects in the final product.

\section{Mesh size of nuts}

$-16+50$ mesh i.e; $90 \%$ or more of the material passes through a 16 mesh sieve (particles smaller than $1.19 \mathrm{~mm}$ ) and $90 \%$ or more of the nut mixture is retained by 50 mesh sieve (particles larger than $0.297 \mathrm{~mm}$ ) (Sigma-aldrich, USA).

\section{Thandai Preparation}

The method of manufacture of thandai is depicted in Figure 2. Mixed milk of superior quality was filtered and standardized for adjustment of fat levels. Further, the milk was homogenized in 2stage homogenizer (Goma engineering Pvt. Ltd., Mumbai) at a pressure range of 2500 and 500 psi at It $^{\text {st }}$ and II ${ }^{\text {nd }}$ stage, respectively. The purpose of homogenization was to avoid further development of cream plug on the top of the bottles. To the homogenized milk, refined cane sugar and food grade apple green colour were added and mixed properly for uniform dispersion of the constituents. Weighed amount of nuts mixture was added in the product and the mixture was mixed properly with hand blender (Philips, 250 watt). To the prepared beverage, thandai and cardamom flavours were added and mixed thoroughly. Further, the contents were filled in glass bottles leaving a head space of 1.5-1.7 inches, crown corked and pasteurized. Then the bottles were immediately shifted into refrigerator for four to six hours to 
ensure proper pasteurization as well as to cool down the contents in bottles to $5-7^{\circ} \mathrm{C}$ and mark them ready for consumption.

\section{Packaging and storage of product}

Heat stable good quality glass bottles were procured from the Experimental Dairy Plant, College of Dairy Science and Technology, Guru Angad Dev Veterinary and Animal Sciences University, Ludhiana. All the bottles were first pre-rinsed, treated with caustic detergent at $70^{\circ} \mathrm{C}$ and finally rinsed with good quality water (Ranken and Kill 1993). Further, the bottles were sterilized in a hot air oven for at least $160^{\circ} \mathrm{C}$ for 45 to 60 minutes, for complete destruction of any microbial flora. The contents must not be removed from the oven immediately as a slow cooling period is necessary - ideally when the temperature has reduced down to not less than $50^{\circ} \mathrm{C}$. The reason for the gradual cooling period is to avoid the cracking of glassware as well as preventing air (that could potentially contain contaminating organisms) entering the oven (Anon 2010a).

\section{Sensory evaluation}

The sensory evaluation of prepared samples was conducted in College of Dairy Science and Technology, Guru Angad Dev Veterinary and Animal Sciences University, Ludhiana, with a panel of total seven semi-trained members including female and male panellists between age group of 35-45 years. Prior to sensory evaluation, sensory panel was briefed about the desirable characteristics of the product. Nine-point hedonic scale was employed to carry out the evaluation of samples (Amerine et al. 1965; Shone et al. 1979) with a view to access the favourable reception of the optimized formulation concerning the sensory attributes of colour and appearance, flavour, mouth feel and consistency, sweetness as well as overall acceptability, a 9point structured hedonic scale test. The samples were served in cups with caps (to ease shaking of contents), coded with random alphabets, containing $25 \mathrm{~mL}$ of the beverage.

\section{Physico-chemical analysis}

\section{Total and Reducing sugars}

Sugars were determined following the method prescribed by BIS (1981). Accurately weighed $40 \mathrm{~g}$ of sample was taken in $100 \mathrm{ml}$ beaker to which $50 \mathrm{ml}$ of hot water $\left(80-90^{\circ} \mathrm{C}\right)$ was added and after thorough mixing, contents were transferred to $250 \mathrm{ml}$ volumetric flask. Final volume was made up to about $120-150 \mathrm{ml}$. The contents in the volumetric flask were then mixed and cooled to room temperature followed by addition of $5 \mathrm{ml}$ of $10 \%$ dilute ammonia. After 15 minutes, $5 \mathrm{ml}$ of $10 \%$ dilute acetic acid was added to neutralize the added ammonia. To this was added, $12.5 \mathrm{ml}$ zinc acetate solution followed by $12.5 \mathrm{ml}$ of potassium ferrocyanide solution and mixed again. Finally content was made to $250 \mathrm{ml}$ volume using distilled water and further filtered through Whatman no. 1 filter paper. The filtrate thus obtained was marked as $B_{1}$.
From $\mathrm{B}_{1}, 25 \mathrm{ml}$ was taken into a $100 \mathrm{ml}$ volumetric flask and $5 \mathrm{ml}$ of conc. $\mathrm{HCl}$ was added followed by heating at $68^{\circ} \mathrm{C}$ for 5 minutes. The same was cooled and neutralized with $50 \% \mathrm{NaOH}$ and made upto $100 \mathrm{ml}$ with distilled water and was marked as $\mathrm{A}_{1}$. The solution marked as $A_{1}$ was diluted 20 times while $B_{1}$ was diluted 4 times and were marked as $A_{2}$ and $B_{2}$ respectively. Both the solutions were taken into a burette and titrated against the mixture of $5 \mathrm{ml}$ each of Fehling A and Fehling B solutions added with a mixed indicator. Similarly, standard lactose and sucrose were taken and titrated. For calculation, the following formula was used:

$10 \mathrm{ml}$ of Fehling $(\mathrm{A}+\mathrm{B})$ solution $=\mathrm{V}_{1} \mathrm{ml}$ of standard invert sugar solution of concentration $\mathrm{C}_{1} \mathrm{mg} / \mathrm{L}$ (i.e. $\mathrm{C}_{1}=2.5 \mathrm{mg} / \mathrm{ml}$ )

$10 \mathrm{ml}$ of Fehling $(\mathrm{A}+\mathrm{B})$ solution $=\mathrm{V}_{2} \mathrm{ml}$ of sample solution before inversion of concentration $\mathrm{C}_{2} \mathrm{mg} / \mathrm{ml}$

$10 \mathrm{ml}$ of Fehling $(\mathrm{A}+\mathrm{B})$ solution $=\mathrm{V}_{3} \mathrm{ml}$ of inverted sample filtrate having concentration $\mathrm{C}_{3} \mathrm{mg} / \mathrm{ml}$

$\mathrm{V}_{1} \mathrm{C}_{1}=\mathrm{V}_{2} \mathrm{C}_{2}$

$$
\begin{aligned}
& \therefore \mathrm{C}_{2}=\frac{\mathrm{V}_{1} \mathrm{C}_{1}}{\mathrm{~V}_{2}} \frac{m g}{m L} \\
& \mathrm{C}_{2}=\frac{\mathrm{V}_{1} \mathrm{C}_{1}}{\mathrm{~V}_{2} * 1000} * \frac{250}{40} * \frac{100}{25} * 100 \% \\
& \mathrm{C}_{3}=\frac{\mathrm{V}_{1} \mathrm{C}_{1}}{\mathrm{~V}_{3} * 1000} * \frac{250}{40} * \frac{100}{25} * \frac{100}{25} * 100 \%
\end{aligned}
$$

\section{Instrumental Colour measurement}

Thandai samples were analyzed for colour attributes ('L', 'a' and 'b' values) at D 65/10 $0^{\circ}$ using Colour Reader CR-10 (Konica Minolta Sensing Inc., USA).

\section{Free fatty acid}

The method prescribed by Deeth et al. (1975) was used to estimate the FFA content of thandai. The method consisted of accurate weighing of $5 \mathrm{~g}$ of sample into a $60 \mathrm{ml}$ stoppered test tube. Ten $\mathrm{ml}$ of extraction mixture (Isopropanol: petroleum ether: $4 \mathrm{~N} \mathrm{H}_{2} \mathrm{SO}_{4}$ in the ratio of (40:10:1) was added and mixed thoroughly. This was followed by the addition of $6 \mathrm{ml}$ petroleum ether and $4 \mathrm{ml}$ distilled water. The test tube was stoppered and tempered at $40^{\circ} \mathrm{C}$ for 10 minutes the contents were vigorously shaken for $20 \mathrm{sec}$. The two layers were allowed to separate for 10-15 minutes and an aliquot of the upper layer $(5-8 \mathrm{ml})$ was withdrawn and titrated against $0.02 \mathrm{~N}$ methanolic $\mathrm{KOH}$ solution using $1 \%$ methanolic phenolphthalein indicator. The FFA content of thandai was obtained from the following formula: 


$$
\mathrm{FFA}(\mu \mathrm{eq} / \mathrm{g})=\frac{\mathrm{TN}}{\mathrm{pW}} \times 1000
$$

\section{ThioBarbituric Acid}

The thiobarbituric acid reactive substances (TBARS) in milk chocolate were determined by following method.

Chocolate samples $(5 \mathrm{~g})$ were dissolved in chloroform and volume was made to $100 \mathrm{ml}$ with chloroform using volumetric flask. Five ml solution was pipetted out and transferred to a centrifuge tube of $20 \mathrm{ml}$. To this, $5 \mathrm{ml}$ of $10 \%$ trichloroacetic acid (TCA) was added and centrifuged at $3,000 \mathrm{rpm}$ for $10 \mathrm{~min}$. After centrifugation, $4 \mathrm{ml}$ of supernatant was mixed with $1.25 \mathrm{ml}$ of $30 \mathrm{mM}$ thiobarbituric acid. The sample was then heated in a boiling water bath for $10 \mathrm{~min}$ and cooled to room temperature. The absorbance was measured at $530 \mathrm{~nm}$ using a spectrophotometer. TBA value expressed in terms of malonaldehyde (MDA) formed during storage periods.

\section{Fiber}

Total dietary fibre content in the product was determined using 'Total Dietary Fibre Assay Kit' supplied by Sigma Aldrich Inc. (TDF-100A). The principle involves gelatinization of samples with heat-stable $\alpha$-amylase and enzymatic digestion with protease and amyloglucosidase to remove the protein and starch present in the sample. Ethanol precipitates the soluble dietary fibre. The filtered residue is washed with ethanol and acetone and weighed after drying. Half of the residue is analyzed for protein and the other half for ash. Total dietary fibre is the weight of the residue less the weight of the protein and ash.

\section{Tyrosine value}

Tyrosine value can be used to check the level of proteolysis in foods. Tyrosine value is useful as a general index of bacteriological and organoleptic quality of commercial raw milk subjected to prolonged cold storage. The tyrosine content as a measure of proteolysis in thandai was determined according to the method of Strange et al. (1977).

Five grams of sample was exactly weighed and taken in a clean dry test tube, added with $10 \mathrm{ml}$ of distilled water followed by

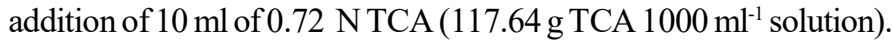
The test tubes were then stoppered shaken vigorously and incubated at $27^{\circ} \mathrm{C}$ for 10 minutes. The precipitated proteins were filtered through Whatman No. 42 filter paper and the tyrosine content in the filtrate was determined. To $5.0 \mathrm{ml}$ of this TCA soluble filtrate, $2.0 \mathrm{ml}$ of distilled water, $10 \mathrm{ml}$ of sodium carbonate reagent $\left(75.0 \mathrm{~g}\right.$ anhydrous $\mathrm{Na}_{2} \mathrm{CO}_{3}$ and $10.0 \mathrm{~g}$ sodium tetra phosphate dissolved in glass distilled water and diluted to 500 $\mathrm{ml}$ ) followed by $3.0 \mathrm{ml}$ of the Folin's phenol reagent (Folin's phenol reagent diluted 1:2 with distilled water) was added, mixed well and incubated again at $27^{\circ} \mathrm{C}$ for 10 minutes for colour development. The intensity of blue colour so developed was measured at $650 \mathrm{~nm}$ using spectrophotometer.

The following regression equation given by Chawla (2010) was used to calculate the tyrosine concentration $\left(\mu \mathrm{g} 5 \mathrm{ml}^{-1}\right)$.

$$
\mathrm{Y}=0.1024 \mathrm{X}+0.1197
$$

Where,

$$
\begin{aligned}
& \mathrm{X}=\text { Concentration of tyrosine in } \mu \mathrm{g} 5 \mathrm{ml}^{-1} \\
& \mathrm{Y}=\text { absorbance at the respective tyrosine }
\end{aligned}
$$

concentration.

\section{Microbiological studies}

Standard plate count, yeast and mold count and coliform count were analysed as per procedure given by Wehr and Frank (2004) using the media Nutrient agar for standard plate count, Potato dextrose agar for yeast and mold and Violet red bile agar for coliform.

\section{Statistical analysis}

The data wasanalysed statistically and the mean comparison was done by Duncan's Multiple Range Test (DMRT). The significance of the results was analysed by the least significant difference (LSD) test. Differences of $\mathrm{p}<0.05$ were considered to be significant.

\section{Results and Discussion}

\section{Effect of storage temperature on sensory scores}

The sensory scores of thandai decreased gradually owing continuous changes occurring in the product such as oxidation of fat, proteolysis, loss of freshness etc. The colour \& appearance, mouth feel \& consistency, sweetness, flavour and overall acceptability scores of fresh thandai at 0 day were $8.33,8.13,8.06,8.04$ and 8.37 , respectively (Table 1 ). The colour and appearance scores started decline significantly after third day in thandai from 8.33 to 6.82 and the colour of product changed from apple green towards whitish green, probably because of degradation of color within the sample during storage as authentified by instrumental colour reader. Also, the decrease in colour scores was statistically significant ( $\mathrm{p} \leq 0.01$ ). Similar findings were observed by Hassan et al. (2015) in fruit flavoured milk beverage for decrease in colour scores during storage. Similarly, scores of mouthfeel and consistency of thandai samples decreased significantly after fourth day from 8.13 to 6.74 . However, non- significant difference was observed in mouthfeel scores in samples during last three days of storage study. Overall the study marked significant difference $(\mathrm{p} \leq 0.01)$ in mouth feel and consistency scores. 
Sweetness scores also decreased significantly $(p \leq 0.01)$ for thandai samples, from an initial value of 8.06 to 6.72 (Table 1). It can be inferred from the scores that though the sweetness did not decrease during the course of time. However, the perceivable intensity of the product declined progressively and might be due to the changes occurring in reducing and total sugar content. Yadav et al. (2010) also reported decrease in sweetness scores in whey-based beverage during storage. Huge variations in the sensory scores could also be attributed to personal sensory preference of an individual and increase in off flavours, developed during storage; interrupting accurate judgment. Flavour scores decreased from initial value of 8.04 to 6.62 after 10 days at refrigeration temperature and this decrease in scores might be due to oxidation of nuts and lipolytic rancidity of milk fat during storage which led to inherent loss in freshness of the product. Mittal and Bajwa (2014) also reported decline in sensory scores of flavour in cardamom flavoured pasteurized milk.

Overall acceptability, the average of various sensory parameters which further depends on several factors like proteolysis, lipolysis, flavour changes and microbiological activity, also decreased during storage (Table 1) from 8.37 to 6.87 for thandai samples. The sensory analysis was terminated once the SPC count crossed permissible limits, as dictated by FSSAI for flavoured milk. Estimated means of sensory scores as computed by statistical analysis of the data clearly indicated that storage period had significant effect $(\mathrm{p} \leq 0.01)$ on all the sensory attributes (Table 1 ). The product was sensorily acceptable after 10 days at refrigeration temperature. Decrease in sensory acceptability was corroborated with the findings of Chawla et al. (2018) in fruit pulp fortified lassi.

\section{Effect of storage on physico-chemical parameters of thandai}

Physico-chemical properties are the important parameters to know the stability of any food product during storage study and gives an idea about the shelf life of the newly developed food products. For evaluating the changes, physico-chemical properties of the product were analyzed for changes in tyrosine, reducing and total sugars, creaming index, cream plug formation, free fatty acids, $\mathrm{pH}$ and acidity and instrumental colour on every day.

\section{Tyrosine Value}

Tyrosine value is extent of partial hydrolysis of milk proteins, caused by enzymes present in milk. Protease enzymes indigenous to milk as well as microbial proteases degrade proteins which lead to release of free amino acids like tyrosine, producing bitter taste in dairy products. The degree of proteolysis in thandai samples was recorded in the terms of tyrosine value which increased significantly $(\mathrm{p} \leq 0.01)$ during storage, however the increase was rapid during few last days of storage (Fig 1a). This may be due to prompt action of proteolytic bacteria that developed 


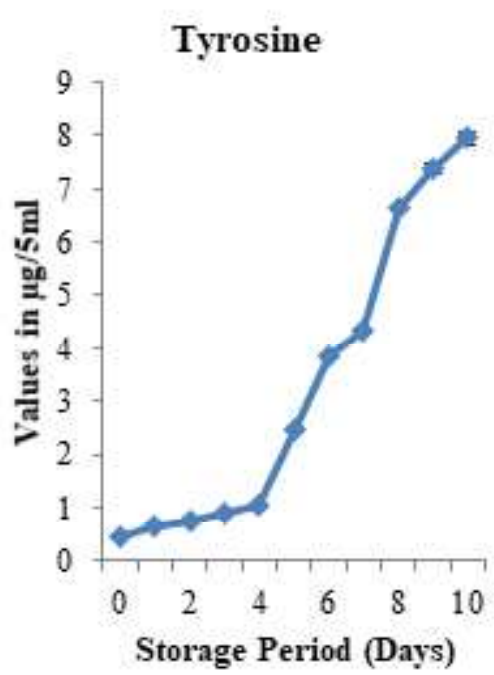

Acidity
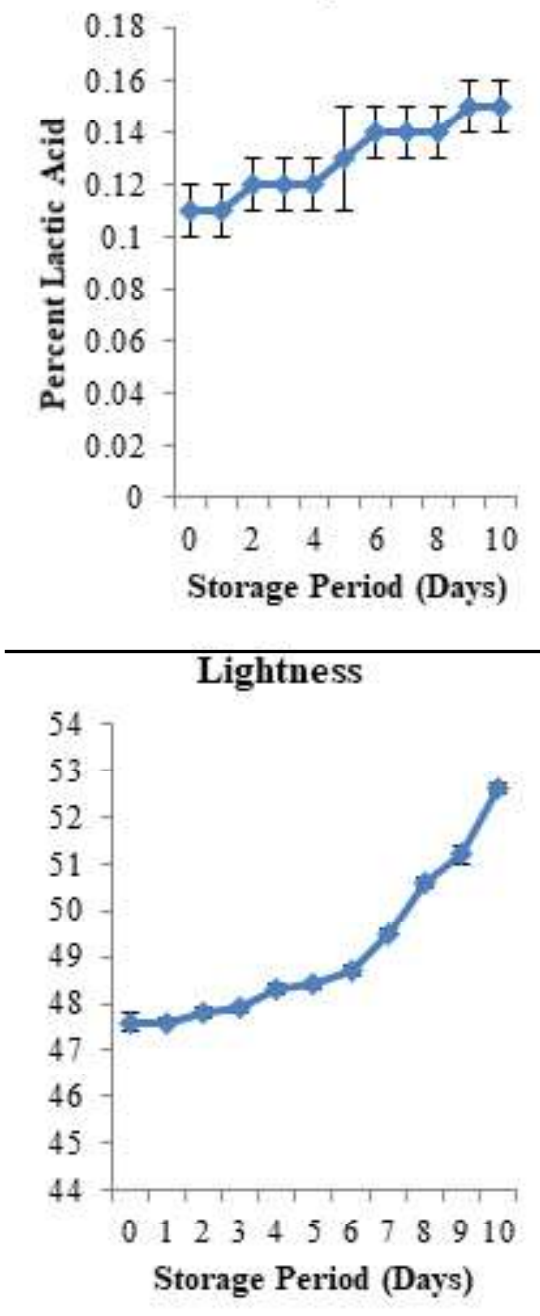

FFA

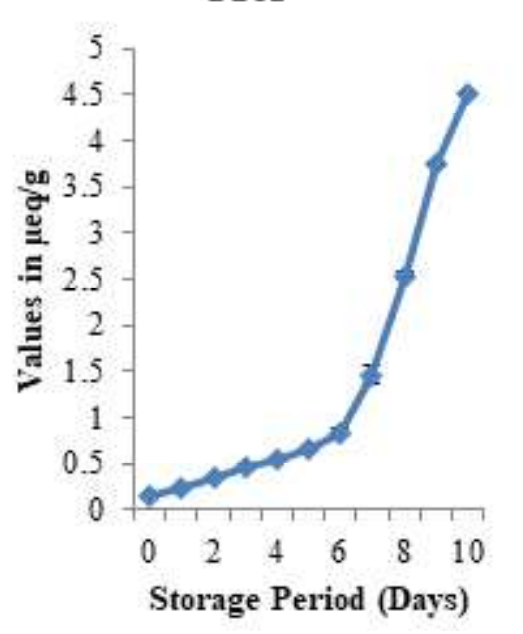

Reducing Sugars

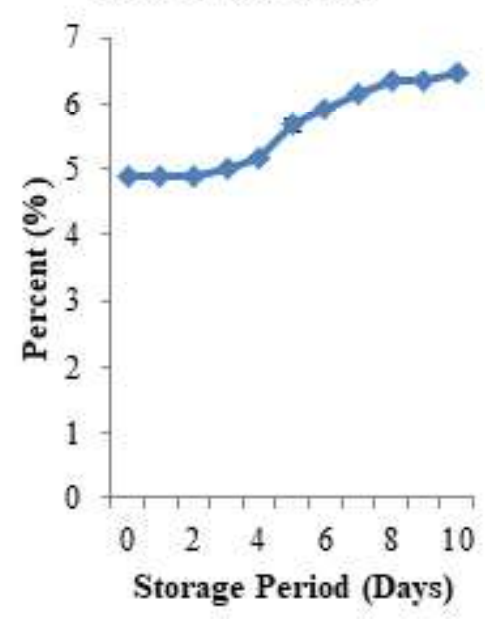

pH

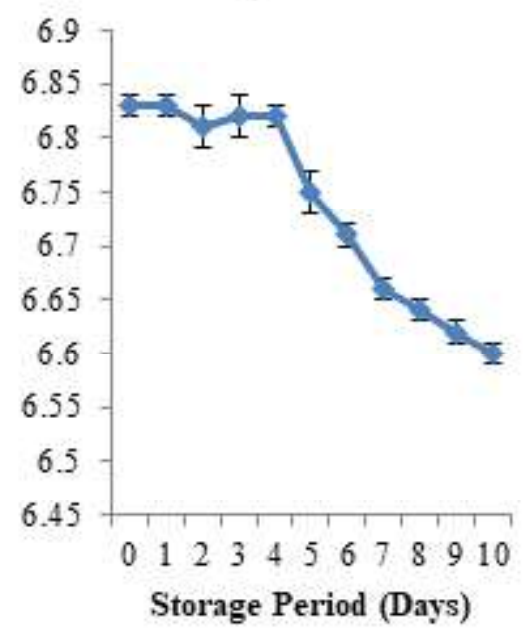

Total Sugars

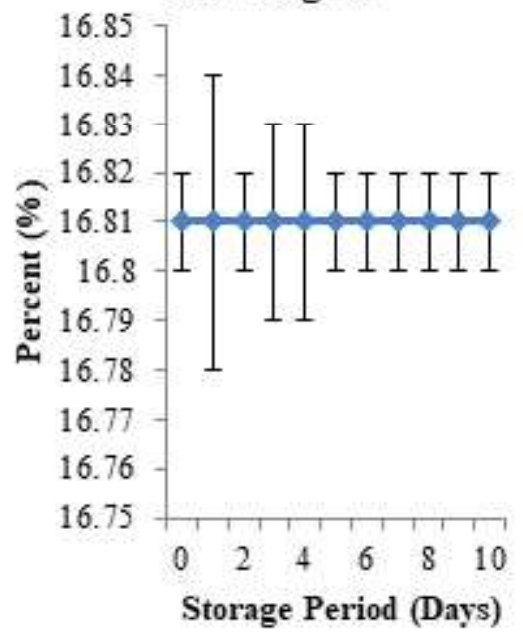

Yellowness
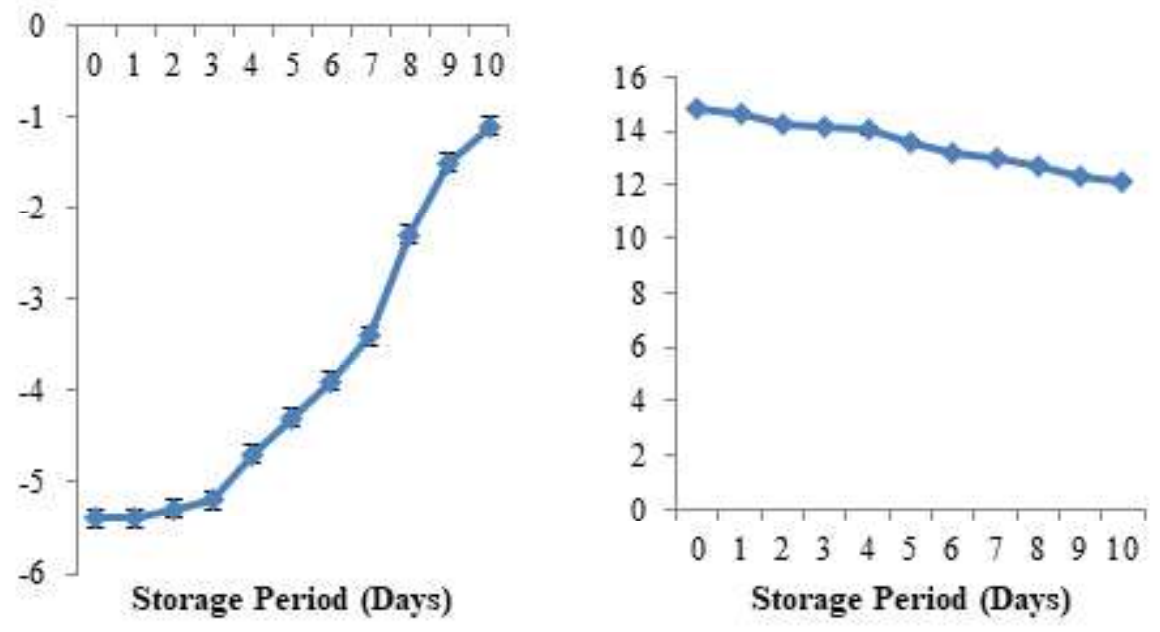

Fig. 1a-i: Effect of storage period on physico-chemical attributes of thandai 


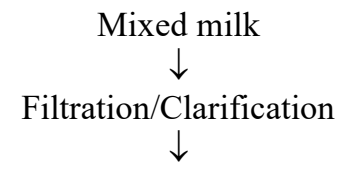

Standardization (either cream separation/skim milk addition or addition of high fat milk/cream)

$\downarrow$

Homogenization at $\mathrm{I}^{\text {st }}(2500 \mathrm{psi})$ and $\mathrm{II}^{\text {nd }}$ stage (500 psi)

$\downarrow$

Addition of refined cane sugar and food grade colour

$\downarrow$

Addition of grinded nuts (almonds and various seeds) \{Mesh size: $-16+50$ mesh $\}$

$\downarrow$

Addition of thandai and cardamom flavours

$\downarrow$

Thoroughly mixed with hand blender

$\downarrow$

Filling in washed and pre-dried glass bottles

$\downarrow$

Crown corking

$\downarrow$

In-bottle pasteurization $\left(88^{\circ} \mathrm{C} / 7\right.$ minutes $)$

$\downarrow$

Immediate Cooling to refrigeration temperature $\left(5^{\circ}-7^{\circ} \mathrm{C}\right)$

Fig. 2 Flow diagram for preparation of RTS thandai beverage

Table 2 Effect of storage period on microbiological attributes of thandai

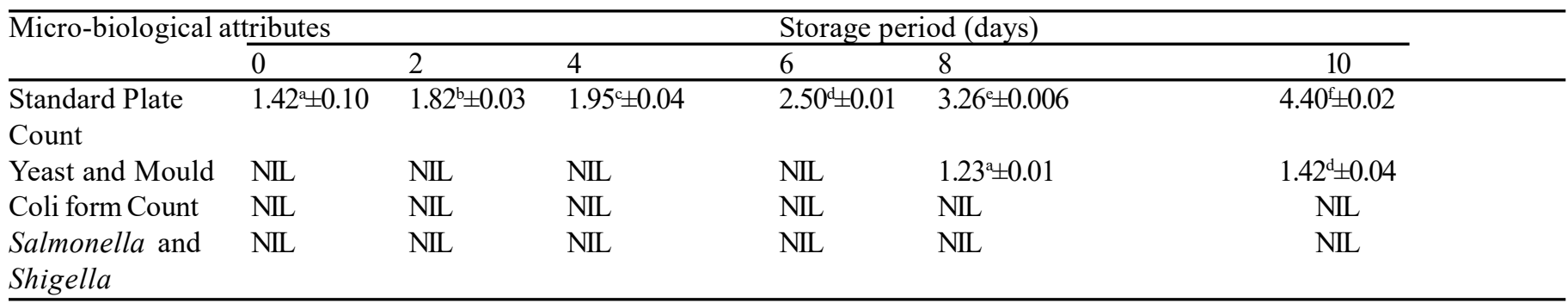

Values bearing different alphabets within rows vary significantly $(\mathrm{p} \leq 0.01)$

in thandai during storage and value increased from $0.47-7.95 \mu \mathrm{g} /$

$5 \mathrm{ml}$ in samples after storage of 10 days. Similar increase in tyrosine value has been reported by Hussain et al. (2014) in sorghumbased milk beverage and Shah and Prajapati (2014) in fermented milk.

\section{Free fatty acids}

Lipolytic changes occur in fat-based products during storage as a result of extracellular thermo-stable lipases produced by microorganisms. This causes development of off-flavours as a result of increase in free fatty acids value. The extent of fat oxidation was measured as FFA which was found significant $(\mathrm{p} \leq 0.01)$ and varied from $0.15-4.52 \mu \mathrm{eq} / \mathrm{ml}$ (Fig 1b). The probable reasons for increase in free fatty acids may be oxidation of fat present in milk and nuts. Increase in FFA values have been reported by Narayanan et al. (1993) in UHT processed soy beverage and Hussain et al. (2014) in sorghum-based milk beverage

\section{Reducing and Total sugars}

Reducing sugars comprised of natural sugars derived from milk (lactose) as well as nuts. Total sugars are sum total of both added sugars and reducing sugars. Non-statistical significant change was observed in total sugar content of thandai samples during the storage study (Fig 1e,f). Similar trend was reported by Yadav et al. (2010) for total sugars during storage of whey-based banana beverage.

However, the reducing sugar content increased significantly $(\mathrm{p} \leq 0.01)$ in thandai samples. Similar trend was reported by Akhtar et al. (2013) during storage of Pomegranate based drink as well as by Yadav et al. (2010) in whey-based banana beverage. 


\section{pH and Acidity}

$\mathrm{pH}$ and acidity of thandai varied significantly $(\mathrm{p} \leq 0.01)$ throughout the storage period of 10 days. Similar trend was reported by Kilima et al. (2014) in roselle fruit juice blends and Mittal and Bajwa (2014) in cardamom flavoured pasteurized milk. However, non-significant differences were observed in acidity and $\mathrm{pH}$ values upto fourth day of storage study (Fig 1 $\mathrm{c}, \mathrm{d})$. Though, $\mathrm{pH}$ and acidity values varied from 6.83-6.60 and $0.11-0.15 \%$ lactic acid, respectively in thandai.

\section{Instrumental Colour}

The changes in colour of thandai stored at refrigeration temperature in terms of lightness $\left(\mathrm{L}^{*}\right)$, redness $\left(\mathrm{a}^{*}\right)$ and yellowness $\left(b^{*}\right)$ were recorded and are reported in Figure 1. Lightness value increased in the samples and varied from 47.60 to 52.60 (Fig $1 \mathrm{~g}$ ) The colour of thandai changed from apple green to off green with more white undertones, and can be due to decrease in colour intensity due to various physico-chemical changes. The results can be well complimented with decrease in sensory scores for colour and appearance during storage. The $a^{*}$ value indicates that the product is green in colour which decreased during storage from -5.40 to -1.10 in thandai at refrigeration temperature. The colour moved towards redness $\left(+\mathrm{a}^{*}\right)$ value and can be attributed to oxidation of nuts present in thandai in the presence of oxygen which produced slightly unidentified reddish brown colour in thandai. However, the change in colour values was so small that it was not visible to naked eye though proved intrumentally.

Yellowness $\left(\mathrm{b}^{*}\right)$ of thandai samples decreased during storage (Fig $1 \mathrm{~h}$ ). The value decreased from initial value of 14.80 to 12.10 for thandai. Statistically ( $\mathrm{p} \leq 0.01)$ significant difference in colour attributes was marked for thandai samples. Comparable trends for all the three colour attributes were observed in UHT milk storage study by Jovanka et al. (2008).

\section{Effect of storage on microbial quality of thandai:}

Milk products serve as a good substrate for the microbial proliferation. Lower moisture content and high sugar content in the sweets pose a hurdle to microbial growth. But the product under investigation contained good amount of sugar along with high moisture content, so comparatively higher microbial growth was expected, however coliform as well as salmonella and shigella counts were not detected during entire storage period in thandai samples (Table 2).

\section{Standard plate count}

The standard plate count of thandai increased during storage and there was significant $(p \leq 0.01)$ increase observed in SPC of thandai at storage conditions. From a fresh thandai with a count of $1.42 \log \mathrm{cfu} / \mathrm{ml}$, values increased to $4.40 \log \mathrm{cfu} / \mathrm{ml}$ at last day of storage. Anurag et al. (2017) reported that increase in SPC could be due to favourable environmental factors like temperature, relative humidity, storage conditions and food factors like $\mathrm{pH}$, water activity, moisture and nutrients present.

\section{Yeast and Mould Counts}

The yeast and mould count of fresh thandai was nil on ' 0 ' day of storage (Table 2). However, with the progress in storage, period growth was detected in thandai on $8^{\text {th }}$ day. This could be attributed to the improper power regulating due to summers or by direct aerial contamination. The increase in acidity during storage also led to favourable environment for the growth and multiplication of yeast and mould. Statistically significant $(p \leq 0.01)$ differences in yeast and mould counts were observed in last two days of storage.

\section{Conclusions}

From the above investigation, it can be concluded, that RTS beverage can be stored pretty well for 10 days. Though decrease in sensory scores and increase in degradation of product is measurable with progressive storage. However, product remains acceptable under the range liked moderately. Also, preparation of RTS nutty beverage is a delicacy for those who like traditional drinks with goodness of natural and healthy ingredients. Therefore, beverage serves the purpose of satiety, wholesomeness and nutrition at the same time. Also, microbial quality of the product is an assurance for its safe consumption from consumer point of view.

\section{References}

Akhtar S, Ali J, Bilal J, Khan F (2013) Studies on the Preparation and Storage Stability of Pomegranate Juice Based Drink. Middle-East J Sci Res 16:191-95

Amerine M A, Pangborn RM, Roessler E B (Eds) (1965) Principals of Sensory Evaluation of Food pp 338-339. Academic Press, New York

Anon $2010_{\text {a }}$. Sterilization methods for glassware in a laboratory hot air oven. http://www.jimengineering.com/blog/sterilizing-methods-forglassware-in-a-laboratory-hot-air-oven/. Cited on 25 March, 2017.

Anurag, Chawla R, Khatkar S K, Bhaskar D (2017) Effect of temperature on physico-chemical and sensory attributes of bottle gourd burfi. Indian J Dairy Sci 70:391-397

Chawla R, Sivakumar S, Mishra SK (2018) Fortification of lassi with vitamin A using natural vegetable powders. Int J Chem Stud 6:26312635

Chawla R, Sivakumar S, Mishra SK, Kaur, M (2018) Characterization of commercial samples of thandai. Int J Chem Stud 6:838-842

Deeth HC, Fitz-Gerald CH, Wood AF (1975) A convenient method for determining the extent of lipolysis in milk. Aus J Dairy Technol 30:109-111

EI-Adawy AT, aha MK (2001) Characteristics and composition of watermelon, pumpkin, and paprika seed oils and flours. J Agri Food Chem 49:1253-1259 
Hassan M, Dar BN, Rather SA, Akhter R, Huda AB (2015) Physicochemical, sensory and microbial characteristics of fruit flavoured milk-based beverages during refrigerated storage. Adv Biomed Pharma 2:132-139

Hussain SA, Garg FC, Pal D (2014) Effect of different preservative treatments on the shelf-life of sorghum malt based fermented milk beverage. J Food Sci Technol51:1582-1587

IS: SP 18 (Part XI) (1981) Handbook of Food Analysis. Part XI, Dairy Products. Bureau of Indian Standards. ManakBhavan, New Delhi

Jovanka V, Raljić P, Lakić N S, Jovanka G, Petronijević L, Barać MB Sikimić VM (2008) Colour changes of UHT milk during storage. Sensors J 8: 5961-5974

Kilima B, Remberg SF, Chove B E Wicklund T (2014) Influence of storage temperature and time on the physicochemical and bioactive properties of roselle fruit juice blends in plastic bottle. Food Sci Nutr 2:181-191

Madaan TR, Lal BM (1984) Some studies on the chemical composition of cucurbit kernels and their seedcoats. Plant Foods Human Nutr 34:8186

Mittal S, Bajwa U (2014) Effect of heat treatment on the storage stability of low-calorie milk drinks. J Food Sci Technol 51:1875-1883

Narayanan KA, Kumar A, Patil GR (1993) Kinetics of various deteriorative changes during storage of UHT soy beverage and development of a shelf-life prediction model. LWT-Food Sci Technol 26:191-197

Ranken MD, Kill RC (Eds). (1993) Food Industries Manual. pp. 77-78. Springer Science+Business Media, New York
Shah N, Prajapati JB (2014) Effect of carbon dioxide on sensory attributes, physico-chemical parameters and viability of Probiotic L. helveticus MTCC 5463 in fermented milk. J Food Sci Technol 51:3886-3893

Shone H, Sidel H, Oliver S, Woodesey A, Singlehon RC (1979) Sensory evaluation by quantitative descriptive analysis. Food Technol 28:2426

Strange ED, Benedit RC, Smith J L, Swift CE (1977) Evaluation of rapid test for monitoring alteration in meat quality during storage in intact meat. J Food Prot 40:843-847

Wani AA, Sogi DS, Singh P, Shivhare US (2011) Characterization and functional properties of watermelon (Citrulluslanatus) seed protein isolates and salt assisted protein concentrates. Food Sci Biotechno 20:877-887

Yadav RB, Yadav BS, Kalia N (2010) Banana herbal (Mentha arvensis) beverage. Am J Food Technol 5:121-129

Yoshida H, Tomiyama Y, Hirakawa Y Mizushina Y (2006) Microwave roasting effects on the oxidative stability of oils and molecular species of triacylglycerols in the kernels of pumpkin (Cucurbita spp.) seeds. J Food Comp Anal 19:330-339 